\title{
As personagens femininas na ficção cética de Machado de Assis ${ }^{1}$
}

\section{Female characters in the skeptical fiction of Machado de Assis}

\author{
Daniel Benevides Soares \\ https://orcid.org/0000-0001-7275-9217 - E-mail: benevides.soares@gmail.com
}

\begin{abstract}
RESUMO
O presente artigo tem por objetivo apresentar o papel das personagens femininas na ficção cética de Machado de Assis. Toma-se por base a interpretação de José Raimundo Maia Neto. Segundo o autor, essa ficção cética apresenta o desenvolvimento de um narrador ao longo das obras de Machado. $\mathrm{O}$ artigo divide-se em três momentos. No primeiro, apresenta-se em linhas gerais o tipo de ceticismo presente na obra de Machado segundo Maia Neto. No segundo, discute-se de modo geral os significados abrangentes das personagens femininas nesse contexto. No terceiro, são analisadas individualmente algumas das personagens machadianas.
\end{abstract}

Palavras-chave: Machado de Assis. Personagens femininas. Ceticismo.

\begin{abstract}
This paper aims to present the role of female characters in the skeptical fiction of Machado de Assis. We take as a basis the interpretation of José Raimundo Maia Neto. According to the author, this skeptical fiction presents the development of a narrator throughout Machado's fiction. The article is divided into three parts. In the first, the type of skepticism present in Machado's

\footnotetext{
${ }^{1}$ Agradeço muito especialmente à leitura generosa de José Raimundo Maia Neto da versão final desse artigo. Esse trabalho é um resultado das pesquisas realizadas no Centro de Estudos em Filosofia Brasileira da Faculdade Católica de Fortaleza. Agradeço o convite para a discussão em torno da temática que resultou nessa publicação feita por Evanildo Costeski no Núcleo de Estudos Brasileiros da Universidade Federal do Ceará.
} 
work according to Maia Neto is presented in its most important elements. In the second, the comprehensive meanings of female characters in this context are discussed in general. In the third, some of the Machado's characters are analyzed individually.

Keywords: Machado de Assis. Female characters. Skepticism.

\section{Introdução}

Nossa apresentação se ampara na interpretação de José Raimundo Maia Neto que analisa o desenvolvimento de uma ficção cética ao longo da obra de Machado de Assis. A partir daí, pretendemos discutir o papel das personagens femininas machadianas nessa ficção cética. Para tanto, a estrutura do artigo contém três seções. A primeira prepara as bases da discussão mostrando os elementos fundamentais da ficção machadiana segundo Maia Neto. Após a discussão desses conceitos, passamos na segunda parte do artigo aos significados gerais que as personagens femininas assumem nessa ficção cética: o mundo, a natureza e a temporalidade. Em seguida, nos detemos em algumas das personagens machadianas analisando sua representação e características, com especial destaque para Virgília, Capitu e Fidélia. Finalizamos com um balanço que considera as personagens femininas em relação aos narradores céticos dos romances principais machadianos com foco narrativo restrito.

\section{Ficção cética}

O debate sobre a relação entre filosofia e a obra de Machado de Assis² é profícuo. Articula-se, basicamente, no pêndulo formado por duas posturas, uma afirmando a proximida$\mathrm{de}^{3}$, a outra, o distanciamento ${ }^{4}$ entre ambas. Para conferir corpo a esse debate ${ }^{5}$, a arrojada leitura proposta por Maia Neto investiga a constituição de um tipo de ceticismo desenvolvido ao longo da ficção machadiana que contém respostas originais para questões céticas presentes nessa tradição.

A perspectiva cética presente na ficção machadiana distingue-se, segundo Maia Neto, de uma postura do próprio escritor. Trata-se de um ponto de vista que é dependente da forma literária, não devendo ser confundido com uma posição filosófica do próprio Machado de Assis.

\footnotetext{
${ }^{2}$ As referências às obras de Machado serão indicadas pela edição das Obras Completas (OC) seguidas do volume e da página.

${ }^{3}$ A esse respeito podemos mencionar a figura do literato-filósofo, componente de uma matriz filosófica colonial que funde elementos céticos, estóicos e salvacionistas e cujo interesse é mais sentir e intuir o mundo do que elucubrar sistematicamente sobre a realidade. Daí decorre a legitimidade da forma literária como expressão filosófica, presente, por exemplo, em Padre Antônio Vieira, Gregório de Matos e Machado de Assis (MARGUTTI, 2013, p. 40). O elemento literário - tais como o diálogo e o aforismo como expressão filosófica é algo que pode ser encontrado também em autores clássicos, como Parmênides, Platão, Pascal, Nietzsche e Wittigenstein (MARGUTTI, 2013, p. 118). Essa matriz colonial pode ser enquadrada na perspectiva defendida pelo filósofo Eric Weil na sua lógica dos discursos filosóficos pelos conceitos de atitude e categoria. $\mathrm{O}$ autor apresenta o discurso filosófico como 16 possibilidades de atitudes-categorias concretas, mais duas formais. A atitude, segundo Weil, representa uma determinada maneira de viver no mundo. Quando o essencial dessa forma de viver é apreendido e expresso em um discurso coerente, tem-se uma categoria. Note-se que se essa expressão se dá no que tradicionalmente se entende com um sistema, este "não é necessariamente um sistema filosófico no sentido ocidental da palavra e não o será nem mesmo habitualmente" (2012, p. 114). Vale mencionar aqui precisamente o exemplo do pirronismo antigo, descrito não como um sistema na acepção de um corpo sistemático de doutrinas, mas como uma habilidade ou atitude mental (MAIA NETO, 2007A, p. 15)

${ }^{4}$ Nesse caso, enquadramos a visão de Miguel Reale, que, no que pese o fato de reconhecer três elementos filosóficos na obra machadiana - ironia, compreensão e metafísica - advoga em favor mais da existência de uma densidade filosófica do que propriamente alguma filosofia desenvolvida pelo Bruxo do Cosme Velho (1973, p. 4-6).

${ }^{5}$ Para um panorama mais pormenorizado e abrangente desse debate, conferir (MARTINS, 2017, p. 43- 78).
} 
Sobre a alegada questão da possibilidade de localizar conteúdo filosófico em obras que não são de forma tipicamente filosófica, mas ficcionais, no caso específico da forma de ceticismo própria ao desenvolvimento dos escritos do Bruxo do Cosme Velho, segundo Maia Neto, ela será indistinguível da forma literária em que é apresentada (2016, p. 278-279).

Tal filosofia cética pode então existir em lugar algum, exceto nos romances e contos de Machado. No caso de Machado, eu poderia achar tão errado abstrair o conteúdo filosófico de sua forma literária quanto analisar a forma literária em abstração ao seu conteúdo filosófico cético (MAIA NETO, 2016, p. 279).

Deixamos já saber que não se trata de imputar o tipo de ceticismo que se desenvolve na figura de um narrador cético ao longo da sua ficção como uma visão de mundo pessoal do próprio Machado. Mas diante do exposto podemos perguntar: afinal, no que consiste esse ceticismo?

Segundo o excurso de Maia Neto, na ficção machadiana existe a busca de um personagem-narrador ideal desde os primeiros contos e cuja versão final chega ao ponto-ótimo com o Conselheiro Aires ${ }^{6}$ (MAIA NETO, 2007B, p. 223). Essa filosofia presente na ficção machadiana se dá pela articulação de alguns conceitos-situações (paz doméstica e vida exterior), tipos-ideais de personagens (tolo/mulheres estratégicas, homens/mulheres de espírito), e por algumas perspectivas (ingênua ou dogmática, estratégica e cética). Fundamental para compreender a proposta de Maia Neto é caracterizar esses conceitos.

Comecemos pela perspectiva ingênua. Sob essa perspectiva, são entendidas as atitudes dogmáticas, no sentido do pirronismo de Sexto Empírico, posto que consideram a possibilidade da eticidade e de verdade no mundo que se sobressai às falsas aparências, constituindo crenças. É, portanto, uma postura não-reflexiva, marcante nos personagens de espírito. Os homens de espírito que não alcançam sucesso na vida social tornam-se problemáticos. Essa perspectiva problemática se encontra principalmente na primeira fase machadiana. É uma postura quase-reflexiva após as desventuras ou a inadequação para com a vida social que se mostra insustentável. A partir daqui o destino desses personagens oferece duas veredas: ou eles encontram uma mulher de espírito que lhes permite construir um lócus alheio à vida social ou, em caso contrário, tornam-se loucos ou suicidas ${ }^{7}$. A terceira perspectiva é chamada estratégica, pois diz respeito a um conhecimento intuitivo que certos personagens possuem das regras da vida social, em grande medida determinada pela aparência. Essa perspectiva é descrita e ensinada no conto Teoria do medalhão. É possível, portanto, encontrar tanto mulheres quanto homens que adotam essa perspectiva, sendo que estes são denominados tolos ${ }^{8}$. Da articulação entre essas perspectivas, resulta uma perspectiva cética definida na segunda fase machadiana como uma saída para a crise que os personagens de espírito vivenciam por não terem mais lugar na ordem social (MAIA NETO, 2007A, p. 25). Definiremos melhor a perspectiva cética quando passarmos ao desenvolvimento dos demais conceitos especificados por Maia Neto no decorrer das fases da ficção machadiana.

Passemos agora às situações. A primeira delas é a vida exterior, que representa a vida social, descrita como campo das aparências, das opiniões e da dualidade. Na primeira fase ma-

\footnotetext{
${ }^{6}$ Ao longo desse excurso, os três momentos céticos fundamentais - zetesis, epoche e ataraxia- não se encontram plenamente desenvolvidos no início da segunda fase da obra machadiana. Assim sendo, a perspectiva cética consiste na progressiva elaboração desses três momentos (MAIA NETO, 2007A, p. 17). Já na primeira fase, estão presentes os elementos precursores desses três momentos, que encaminharão a adoção da perspectiva cética (BERNARDO, 2007, p. 172-173). A versão final combinará uma forma de ataraxia com uma atitude estética perante a vida (MAIA NETO, 2005, p. 11-12)

7 Conferir a esse respeito (MAIA NETO, 2007A, p. 71-74).

${ }^{8}$ Essas perspectivas são teorizadas a partir do ensaio de Victor Henaux De l'amour dês femmes pour lês sots cuja tradução, Queda que as mulheres têm pelos tolos, foi considerado por parte da crítica como sendo da autoria do próprio Machado.
} 
chadiana, a vida exterior tem uma conotação mais negativa, sendo identificada com a hipocrisia e a falsidade, oposta à verdade. Na segunda fase da ficção do Bruxo do Cosme Velho, a vida exterior torna-se hegemônica. Em oposição a ela temos a paz doméstica, configurada como sua alternativa e, portanto, como lugar da verdade, da transparência e da ética. Na primeira fase machadiana, sua representação é o casamento. Após a segunda fase, o casamento também passa a compor a vida exterior, o que resultará na crise cética9 ${ }^{9}$ (MAIA NETO, 2007A, p. 24).

Concluídas as apresentações das condutas e das situações, podemos nos ocupar da tipologia de personagens. Na ficção machadiana se destaca a presença de um triângulo amoroso: dois homens e uma mulher. Essa estrutura encontra-se nos seus romances e em uma parcela significativa dos seus contos. Os dois homens cultivam posições opostas: o tolo e o homem de espírito. De um lado, portanto, temos o tolo, ou o indivíduo estratégico, inteiramente dedicado ao sucesso pessoal e social, não hesitando em mentir ou dissimular caso assim os seus objetivos o exijam (MAIA NETO, 2016, p. 282). Esse tipo é uma primeira versão da perspectiva estratégica. Sua conduta instrumental desvela a incongruência entre a conduta exterior e os seus estados subjetivos. Na primeira fase machadiana são identificados com personagens aéticos, tendo uma caracterização mais negativa, sendo ainda neste estágio da ficção de Machado presente a possibilidade de uma conversão para esses personagens: os tolos podem tornar-se homens de espírito (MAIA NETO, 2007A, p. 38-39; 49-50). O equivalente feminino mais próximo dos tolos são as mulheres estratégicas, menos numerosas na primeira fase machadiana. A partir da segunda fase, as Celestinas cederão lugar às Virgílias (MAIA NETO, 2007A, p. 51-55).

E o homem de espírito? O homem de espírito é comprometido com a verdade e a transparência, e não apenas não sabe como fazer ou se recusa a agir segundo o modo moralmente ambíguo imprescindível para alcançar o sucesso: isso é impossível para ele, pois sua visão de vida é ingênua (MAIA NETO, 2016, p. 282). O homem de espírito é a personagem que adota uma visão ingênua da vida, sendo esta avessa à vida exterior (MAIA NETO, 2007A, p. 24). Nesse sentido, as mulheres de espírito podem ser assemelhadas aos homens de espírito na sua predileção pela paz doméstica em oposição à vida exterior ${ }^{10}$.

Esses conceitos se modificam ao longo do desenvolvimento da ficção machadiana. No período que vai de 1861-1871, temos uma postura dogmática na caracterização desses conceitos. A vida exterior é descrita como campo da mentira oposto à verdade, cuja representação literária é a paz doméstica. O homem de espírito também é determinado dogmaticamente. Mesmo antes de encontrar a verdade, é um pessimista em relação à visão da vida, nos moldes de Pascal e do Eclesiastes ${ }^{11}$. As mulheres de espírito são marcantes nesse período. Elas são o contraponto à falsidade por exibirem um comportamento transparente, sendo, também, a representação literária da verdade. Exemplo de personagens dessa fase são Ângela, do conto Felicidade pelo casamento, e Celestina, do conto Anjo Rafael. Finalmente, o tolo também tem uma caracterização

\footnotetext{
${ }^{9}$ Uma ilustração da importância que a vida social passa a adquirir na segunda fase da obra machadiana pode ser pinçada do conto O espelho, publicado em 1882, segundo a análise de Renata Philipov, muito embora sua interpretação seja diferente de uma matriz cética. De acordo com sua leitura, a alma exterior do alferes é o seu uniforme, pois este é, na verdade, o reconhecimento social, sem o que a alma interna não consegue se manter, chegando à destruição. O espelho que projeta o uniforme do alferes, metaforicamente, representaria a sociedade (PHILIPOV, 2011, p. 45).

${ }^{10}$ Sobre essas semelhanças, conferir (MAIA NETO, 2007A, p. 51-55).

${ }^{11}$ Os paradigmas desse estágio do homem de espírito são o narrador do conto Felicidade pelo casamento e Antero, do conto Anjo Rafael (MAIA NETO, 2016, p. 283). “O Eclesiastes mostra que o homem sem Deus fica na ignorância de tudo e numa infelicidade inevitável, pois é ser infeliz querer e não poder. Ora, ele quer ser feliz e estar seguro de alguma verdade. E, no entanto, não pode nem saber nem não desejar saber. Nem mesmo pode duvidar" (PASCAL, Pensamentos L. 75, B. 389). Esse fragmento ilustra bem o pessimismo presente em Brás Cubas. No estágio do desenvolvimento do narrador cético representado por ele, esse ceticismo ainda não está plenamente configurado.
} 
dogmática, sem uma visão atenuada, sendo descrito negativamente como associado à corrupção e falsidade da vida exterior (MAIA NETO, 2016, p. 283).

"A situação fictícia muda nos contos e romances escritos entre 1872 e 1878" (MAIA NETO, 2016, p. 283). Sofrem mudanças tanto os tipos de personagens quanto as situações. Na etapa anterior, o que tornava inócuo o processo reflexivo encetado pelos homens de espírito era o encontro com a mulher de espírito que ensejava a obtenção da verdade, representada pela paz doméstica. A partir de 1872, a esfera da vida exterior se torna hegemônica, invadindo a paz doméstica ${ }^{12}$, o casamento deixando de ser alternativa à vida social para ser sua via de acesso. Isso se dá porque a perspectiva dogmática é mitigada, tornando menos acerba a caracterização da vida exterior o que também repercute nos personagens tolos, que passam a ser descritos de forma bastante sofisticada. Uma consequência disso é que a perspectiva estratégica perde a conotação manifestamente negativa, como se via na primeira fase, de modo que o casamento pavimenta o caminho para a vida exterior ${ }^{13}$. Os homens de espírito desse período tornam-se personagens fracos. Como a possibilidade do acesso à verdade pela via da paz doméstica é interditada, convertem-se nas chamadas figuras problemáticas, acabando como loucos ou suicidas e perdendo a centralidade na ficção machadiana. Muito mais bem adaptadas a essa nova realidade da hegemonia da vida exterior são as personagens femininas, que, adotando uma perspectiva estratégica, ocupam a vida social com desenvoltura ${ }^{14}$. Será, portanto, com o comprometimento da possibilidade da verdade e o fim da perspectiva ingênua que os homens de espírito tornam-se personagens problemáticos, já as mulheres de espírito cedem lugar para mulheres estratégicas que não adotam a perspectiva ingênua que representava o comprometimento com a verdade dogmática. Com o fim desse dogmatismo, os tolos recebem uma caracterização mais complexa e menos depreciativa e, enquanto os antigos homens de espírito estão atordoados convertendo-se nos personagens problemáticos, desaparecendo da ficção machadiana ou tornando-se marginais, as mulheres de espírito são mais bem-sucedidas ao adotarem as características requeridas pela vida exterior (MAIA NETO, 2016, p. 283-284).

Ficou explicitado o surgimento das perspectivas ingênua e estratégica, mas e a visão cética do narrador, no que ela consiste especificamente?

A segunda fase da obra literária de Machado começa com Memórias Póstumas de Brás Cubas ${ }^{15}$. A principal novidade é o aparecimento da visão cética de vida. $O$ aparecimento desta visão de vida coincide formalmente com aquela do foco narrativo restrito. Esta visão cética (autoria cética) é a primeira solução ao problema do homem de espírito que desaparece - ou vira um personagem marginal - no período de 1872 - 1878 (MAIA NETO, 2016, p. 284).

\footnotetext{
${ }^{12} \mathrm{~A}$ exacerbação desse movimento da caracterização da paz doméstica como local de inquietação ocorre em Dom Casmurro (MAIA NETO, 2016, p. 287).

${ }^{13}$ Conferir a esse respeito (MAIA NETO 2007A, p. 65-66).

${ }^{14}$ Um paralelo ilustrativo é traçado entre as duas Ângelas, a de Felicidade pelo Casamento e a do conto Antes que Cases... uma viúva que muda após o casamento ao voltar-se para a vida exterior, o casamento aqui não sendo mais alternativa, mas porta de entrada para a vida social (MAIA NETO, 2016, p. 284).

${ }^{15}$ Maia Neto considera que a aparição do foco de narração restrito em oposição ao onisciente é um elemento importante que assinala a mudança entre as fases do autor, denominação que o próprio Machado admitia. Ainda segundo ele, esse narrador restrito é determinante para o surgimento da perspectiva cética. Importa pontuar ainda que a segunda fase trata de solucionar problemas encontrados na primeira (MAIA NETO, 2007A, p. 22-27). Não obstante, é ainda possível ver elementos que persistem de uma fase para outra. Citamos dois exemplos. Primeiro, na segunda é ainda possível encontrar alguns elementos dogmáticos, como a relação de identidade entre natureza humana e precariedade e aparências sociais (MAIA NETO, 2007A, p. 78-79). O segundo, é a persistência de personagens que adotam a perspectiva problemática sem tornarem-se céticos, como é o caso de Quincas Borba, que adota essa perspectiva de forma mais refinada e cujo narrador do romance retoma o foco narrativo onisciente (MAIA NETO, 2016, p. 294).
} 
O narrador cético substitui o homem de espírito, com o deslocamento da perspectiva da narrativa que passa a focalizar os próprios memorialistas. Como a solução dogmática não é mais possível, a vida social ocupa toda a realidade e o casamento, de alternativa, sagra-se como o próprio centro da vida exterior. Sem verdade, enseja-se a necessidade da investigação cética. As personagens femininas passam a exibir, diante do observador cético, a polissemia das aparências da vida social, sempre tendo em vista que a verdade não é mais acessível e a essência não é mais transparente nos atos em relação aos quais subjaz (MAIA NETO, 2016, p. 284). Esse é o caráter específico da filosofia vista na ficção machadiana.

Os céticos antigos, bem como Sócrates antes deles, afirmavam que a investigação filosófica pode ser feita apenas enquanto não se assume que a verdade foi descoberta, pois é precisamente sua busca. 'Cético', significa, etimologicamente, 'investigador' (MAIA NETO, 2016, p. 282).

Como ponderação final, importa acrescentar uma palavra o tipo de ceticismo presente na ficção machadiana. Não se trata de uma estrita identificação da filosofia encontrada na ficção de Machado com o ceticismo pirrônico. No que pese a existência de afinidades com a tradição iniciada por Pirro de Élis ${ }^{16}$, a posição filosófica encontrada no Bruxo do Cosme Velho insere-se na rica tradição do ceticismo pirrônico moderno, presente em filósofos como Pascal, Montaigne, Erasmo, Hume e François de La Mothe le Veyer ${ }^{17}$.

Esboçado em linhas gerais o retrato do ceticismo na ficção machadiana, passemos ao segundo momento do nosso trabalho analisando a significação geral que as personagens femininas apresentam nesse quadro.

\section{Pequeno Panteão}

A partir da publicação das Memórias Póstumas de Brás Cubas, as personagens femininas adquirem uma função representativa marcante. Elas passam a representar toda a vida social que é inacessível para além das aparências ao observador cético (MAIA NETO, 2016, p. 284). É nesse sentido que essas personagens passam a desempenhar uma função de metonímia em relação à vida social, posto estarem, junto aos homens estratégicos, mais bem adaptadas à hegemonia da vida social em comparação com os herdeiros dos primeiros homens de espírito, cuja alternativa a se tornarem personagens problemáticos é a atitude da progressiva constituição de um narrador cético.

As personagens femininas exercem uma metonímia não apenas para a vida social, mas para a realidade como um todo quando se considera o horizonte cético (BERNARDO, 2007, p. 174). Essa realidade mostra-se cambiante, indecifrável, (MAIA NETO, 2007A, p. 40-41) e como não é mais possível identificar uma relação de identidade entre essências e aparências - um

\footnotetext{
${ }^{16}$ Entre a tradição pirrônica e o ceticismo acadêmico, Maia Neto considera a primeira mais relevante para a ficção cética machadiana graças aos elementos moral e prático $(2016$, p. 281) Isso não significa que o ceticismo de Carnéades não possa fornecer um horizonte de compreensão para elementos da posição cética vista na ficção machadiana. Em Dom Casmurro, por exemplo, o probabilismo carnedeano - que defende que no campo prático apenas a verossimilhança e probabilidade são dignas de confiança - pode ser exemplificado na verossimilhança entre Ezequiel e Escobar (MAIA NETO, 2007B, p. 222). Sobre as diferenças entre as tradições céticas acadêmicas e pirrônicas conferir (POPKIN, 2000 p. 13-16).

${ }_{17}$ Conferir a esse respeito (MAIA NETO, 2007B, p. 212; 224), bem como (MAIA NETO, 2016, p. 290-291). Margutti considera que o tipo de ceticismo localizado na ficção do Bruxo do Cosme Velho seria mais coerente com um pessimismo cético do tipo presente em Francisco Sanches (p. 203-209). Embora Machado não possuísse em sua biblioteca livros de Sanches (MAIA NETO, 2007B, p. 217-218), Margutti considera que as ideias do cético ibérico repercutiram no Bruxo do Cosme Velho de modo indireto, pela partilha de uma matriz filosófica comum (MARGUTTI, 2007, p. 210). Sobre a matriz filosófica colonial e sua relação com o ceticismo machadiano ver (MARGUTTI, 2007, p. 183- 187). Conferir também (MAIA NETO, 2007B, p. 213-216).
} 
gesto torna-se polissêmico - as aparências contraditórias (MAIA NETO, 2007B, p. 17) exigem uma suspensão do juízo sobre seu significado - uma epoche.

A riqueza polissêmica não é apenas inerente aos gestos quando em um contexto de uma filosofia cética presente na ficção machadiana. A mulher representa também aspectos variados e fundamentais da existência e da realidade, como o mundo, o tempo e a natureza. Vamos agora apresentar brevemente esses três aspectos a partir da chave de compreensão que as personagens femininas oferecem. Como Pandora serve como arquétipo para a compreensão da natureza, utilizaremos como analogia as figuras de Geia e Láquesis para os demais elementos.

Mundo. Comecemos pelos aspectos mundo e realidade. As mulheres de espírito presentes na primeira fase machadiana representam o aspecto do mundo e da realidade oposto à vida exterior, quando esta é caracterizada dogmaticamente e sem matizes como o oposto da verdade. A paz doméstica identificada com a verdade representa uma alternativa à vida exterior, então esfera das aparências ilusórias, dualidades, joguetes e estratagemas. A partir da segunda fase machadiana a crise cética começa a se constituir de modo que a perspectiva ingênua torna-se impraticável, pois a verdade se perde com o dogmatismo e as aparências da vida social tornam-se hegemônicas: a partir de então, as mulheres estratégicas superam em quantidade as mulheres de espírito (MAIA NETO, 2007A, p. 42). A partir dos contos de 1871, a vida social - e com ela a perspectiva estratégica - não aparece mais de forma tão dogmática como nas obras anteriores. Desse modo, o casamento muda de significado, agora tornado acesso para a vida exterior (MAIA NETO, 2007A, p. 65-66).

A partir de então, as personagens femininas estratégicas representam tanto o mundo social, a vida exterior e todas as características que serão apresentadas ao longo do desenvolvimento das ações de três figuras proeminentes - Virgília, Capitu e Fidélia -, tais como, respectivamente, o caráter dúbio, opaco e intercambiável das aparências, quando a própria realidade em si mesma ${ }^{18}$. A postura de cada um dos narradores céticos machadianos - Brás Cucas, Dom Casmurro e Conselheiro Aires -, enquanto personagens ou narradores ${ }^{19}$ diante das personagens femininas, marca um estágio do desenvolvimento do ceticismo. Desse modo, temos a representação de todo o mundo, da realidade enquanto totalidade das coisas humanas que pode ser simbolizada pela figura de Geia. A deusa representava o princípio de onde saíram todas as coisas ${ }^{20}$.

Temporalidade. Passemos agora ao aspecto tempo. Segundo Maia Neto, a mulher também representa simbolicamente o tempo em Machado de Assis (2007A, p. 56): "É sobretudo através da mulher que o tema da temporalidade entra na ficção machadiana" (MAIA NETO, 2007A, p. 56). Na ficção machadiana, o tempo é o componente de algo ainda mais fundamental. "As mulheres em Machado representam a vida. Associam-se, pois às dimensões fundamentais desta última, entre as quais se destaca a temporalidade" (MAIA NETO, 2007A, p. 135). Consoante com esse aspecto, a figura de Láquesis uma das parcas, aquela entre as três irmãs responsáveis por segurar o fio da vida e por distribuir a sorte entre tudo aquilo que vive pode representar esse aspecto fundamental da realidade ${ }^{21}$. Fato digno de nota é que essa deusa ocasionalmente era confundida com a Natureza 22 .

Natureza. Finalmente, tomemos o aspecto natureza. Trata-se de uma personagem importante na ficção machadiana ${ }^{23}$. A natureza aparece como dotada da capacidade de exceder a

\footnotetext{
${ }_{18}$ Conferir a esse respeito (MAIA NETO, 2016, p. 284-292).

${ }^{19}$ Maia Neto distingue entre personagem atuante ou engajado e narrador reflexivo ou recuado, o que diferencia, por exemplo, o Brás Cubas vivo do defunto-autor e Bentinho do Dom Casmurro memorialista (MAIA NETO, 2016, p. 293).

${ }^{20}$ Conferir (GUIRAND, 2006, p. 181).

${ }^{21}$ Conferir a esse respeito (GUIRAND, 2006, p. 326); (MARCH, 2015, p. 40) e (COMMELIN, 1997, p. 83).

22 (COMMELIN, 1997, p. 7).

${ }^{23}$ Segundo Caldwell, mesmo em Dom Casmurro é possível encontrar a associação entre Pandora e a natureza. Conferir a esse respeito: (2008, p. 137-138). Se Geia pode ser confundida com a Natureza e Láquesis pode significar tanto aquela que dá ou tira a
} 
compreensão cabal e exaustiva do ser humano, tendo em vista a crítica que Machado faz de filosofias como o positivismo e ideias como o darwinismo social ${ }^{24}$. O exemplo encontra-se em Memórias póstumas de Brás Cubas quando é essa personagem feminina que faz surgir a compreensão problemática por excelência do observador cético (MAIA NETO, 2007A, p. 102). "Pandora é uma mulher cuja opacidade é uma intensificação dessa característica fundamental da personagem machadiana" (MAIA NETO, 2007A, p. 102). Já sabemos que a opacidade será o atributo por excelência da indecifrável Capitu. Temos então em Pandora uma hipérbole da função exercida pela personagem feminina como representante por metonímia do caráter incompreensível da vida social. No caso de Pandora, essa incompreensibilidade alcança toda a realidade. Pandora, personificação feminina da natureza, estabelece com Brás Cubas uma relação:

Estabelece-se entre Brás Cubas e Pandora uma relação cognitiva cética quanto à caracterização do objeto, observando-se a presença do tropo de Enesidemo, 'baseado nas quantidades e formações dos objetos considerados ${ }^{25 \prime}(\mathrm{PH} 1,37)$. Quanto ao sujeito, observase a perplexidade do observador diante do insólito objeto. A referência à sua mudez nos parece uma figuração da afasia pirrônica que impede o filósofo de fazer asserções sobre o objeto que examina (MAIA NETO, 2007A, p. 102).

A quantidade aqui é imensurável. Pandora é, portanto, inapreensível.

\section{Mulheres estratégicas}

Nesta seção, analisamos de forma individualizada algumas das personagens mais marcantes $^{26}$ do Bruxo do Cosme Velho tendo como moldura a filosofia cética. Começamos com uma personagem estratégica da primeira fase e em seguida analisamos sua evolução dada na segunda fase machadiana.

Helena. É uma personagem cujo nome guarda um significado relacionado com a trama. Remetendo à tragédia homônima de Eurípedes, de acordo com Maia Neto, a personagem apresenta como característica das tragédias a cisão entre sentimentos e deveres cuja oposição a levam até a destruição (2013, p. 59). “Em certo sentido, a personagem de Machado é uma mera quimera (pois simula ser quem não é) que se destrói após a revelação de sua verdadeira identidade" (MAIA NETO, 2013, p. 59).

Marcela. Em Memórias póstumas de Brás Cubas, a cortesã ${ }^{77}$ Marcela aparece como aspecto da vida exterior que inicialmente desvia Brás Cubas da perspectiva estratégica enqua-

sorte, Pandora é a pan dôron, aquela que tem todos os presentes, pois fora adornada com todos os dons dos deuses (GUIRAND, 2006, p. 190 -191).

${ }^{24}$ Conferir (MAIA NETO, 2005, p. 11-12).

${ }^{25}$ Enesidemo, discípulo de Pirro, identifica dez aporias sobre o acordo entre fenômenos e juízos, classificados como modos. Tais incluem a diferença de percepção entre prazer e dor nos seres vivos, as idiossincrasias achadas nos indivíduos, aos sentidos que transmitem as sensações - sentidos diversos conferem impressões diversas sobre um mesmo objeto -, as condições de saúde ou doença, as leis, crenças e tradições, as distâncias e posições no instante de enunciar juízos, quantidade, freqüência e relação entre as coisas (DIÔGENES LAÊRTIOS, 2008, p. 273-274). Sexto Empírico compilou os dez modos (ou tropoi atribuídos a Enesidemo e os cinco tropoi atribuídos a Agripa (MAIA NETO, 2007A, p. 17-19).

${ }^{26}$ Segundo Ribeiro, em quatro das obras machadianas - Helena, Memórias póstumas, Quicas Borba e Dom Casmurro - as personagens femininas ocupam papel bastante central, no que pese o fato de que tal papel seja disfarçado pela presença de um protagonista - ou narrador, na metade deles - masculino (2006, p. 228-229).

${ }^{27}$ A partir do período compreendido pelo Segundo Império francês, especialmente após 1860, surge um novo paradigma de cortesã, como uma "popular personalidade pública", afeita ao uso de disfarces e subterfúgios (MOARES, 2019, p. 320). No Brasil, essa mudança ocorreria de forma mais lenta, na virada do século XIX para o XX (MOARES, 2019, 321). "Afinal, na sociedade brasileira do fin-de-siècle, o novo apetite burguês se acomodava a antigos valores patriarcais, católicos e escravocratas, estabelecendo parâmetros bem diferentes dos europeus para as equações locais entre forma literária, erotismo e moralidade. Mesmo assim, em condições históricas distintas, os modos de fabular a prostituição também passaram por transformações significativas" (MOARES, 
drando-o nos trilhos da perspectiva ingênua. Quando Brás Cubas se dá conta da contradição entre a natureza enganosa e as aparências sociais de Marcela, essa perspectiva ingênua começa a soçobrar. São as "ideias fixas ${ }^{28 "}$ que o personagem cultiva que ainda sinalizam que uma perspectiva cética está distante de consolidar-se (MAIA NETO, 2007A, p. 106-108). Na sua aparição posterior, com a beleza destroçada pela bexiga, Marcela surge como um elemento perturbador que susta a ação ${ }^{29}$, consequentemente, a possibilidade da imersão na vida exterior. É uma experiência cujo feixe também é composto pela aparição anterior de outra personagem feminina: Eugênia. Uma terceira personagem também soma-se àquelas que demonstram o caráter precário da condição humana: ao casar-se com Lobo Neves, Virgília (MAIA NETO, 2007A, p. 110).

Virgília. Quando aparece na condição de amante de Brás Cubas, Virgília oferece o ensejo para o recrudescimento da perspectiva cética trazendo a sugestão de que as paixões são gratuitas e que interesses aéticos ${ }^{30}$ governam as relações sociais; planta-se assim uma desconfiança da vida exterior ${ }^{31}$ em um momento em que a paz doméstica não é mais alternativa possível (MAIA NETO, 2007A, p. 111).

Virgília apresenta, assim, a faceta de uma personagem que assume a perspectiva estratégica. Dois exemplos dessa estratégia: primeiro, no momento em que ela recusa a fuga com Brás Cubas para o propósito da "casinha" que receberia os encontros de ambos; fica o propósito, mas a fuga é desnecessária, sendo dona Plácida instrumentalizada para alcovitar o adultério ${ }^{32}$. O segundo momento se dá quando o marido de Virgília é alertado por carta anônima do adultério e ela se desembaraça das acusações com sucesso ${ }^{33}$. Esses dois momentos, amante e esposa, compõem o aspecto dúbio da vida social que é representado na personagem ${ }^{34}$. De acordo

2019, 321). A criação literária de Machado - considerado primeiro autor das letras brasileiras a representar a cortesã fora do paradigma típico do século XIX - que irá refletir essa nova tendência de representação do tipo de personagem não será, entretanto, Marcela, mas sim a Marocas do conto Singular ocorrência datado de 1883 (MOARES, 2019, p. 321-322).

28 "Deus te livre, leitor, de uma ideia fixa; antes um argueiro, antes uma trave no olho. Vê o Cavour; foi a ideia fixa da unidade italiana que o matou. Verdade é que Bismarck não morreu; mas cumpre advertir que a natureza é uma grande caprichosa e a história uma eterna loureira" (OC, I, p. 602-603). Interessante notar aqui que as 'ideias fixas' aparecem na conta de algo distribuído pela natureza ou da enganação de uma cortesã. No primeiro caso, tem-se como representação de Pandora. No segundo, a história apresenta a duplicidade vista em Marcela. Curioso lembrar que uma das prerrogativas de Láquesis é distribuir entre os viventes os presentes da sorte (GUIRAND, 2006, p. 326).

29 Posteriormente, quando Brás Cubas depara-se com Marcela decrépita e macilenta, ela serve de motivo para a caracterização da filosofia do defunto-autor, em oposição ao Humanitismo de Quincas Borba. Se para este trata-se de advogar em favor da transcendência das misérias humanas pela razão bem como de sua divinização, para o defunto-autor trata-se de um ceticismo mais próximo daquele encontrado em Pascal que atesta a mutabilidade dos acontecimentos, a efemeridade da beleza e a constância da miséria humana (MAIA NETO, 2007A, p. 121-122).

${ }^{30}$ Segundo Maia Neto, as ações aéticas devem ser compreendidas no contexto da chamada lei da equivalência das janelas formulada no capítulo LI (OC, l, p. 653-654) e apresentada novamente no capítulo CV (OC, I, p. 698) das Memórias póstumas: "Ações aéticas ou não virtuosas são janelas fechadas na consciência (pois trazem culpa). A consciência é 'arejada' quando se abre outra janela, a saber, uma ação virtuosa" (2007A, p. 113). Eis como o defunto-autor a formula: "Assim eu, Brás Cubas, descobri uma lei sublime, a lei da equivalência das janelas, e estabeleci que o modo de compensar uma janela fechada é abrir outra, a fim de que a moral possa arejar continuamente a consciência" (OC, I, p. 654).

${ }^{31}$ Uma ilustração curiosa desse ambiente de desconfiança são as suspeitas sobre a descoberta do adultério. "Que não são do marido, ou só dele. Já se tornaram públicas e comentam-se no teatro. Levando-se em conta que a população da cidade do Rio de Janeiro, em 1840, era de exatos 137.078 habitantes e que as cenas narradas se passam, provavelmente, em 1842, ano do início da relação entre os dois, pode-se avaliar o tipo de catástrofe que era uma suspeita dessas. Quantos eram os membros da chamada 'boa sociedade', que freqüentavam teatros? De que forma poderia haver alguma privacidade numa cidadezinha minúscula, para os padrões de hoje? Como não ser 'falado', em tal contexto?" (RIBEIRO, 2006, p. 278).

32 "Convencionamos que iria morar ali uma mulher, conhecida de Virgília, em cuja casa fora costureira e agregada. Virgília exercia sobre ela fascinação. Não se Ihe diria tudo; ela aceitaria facilmente o resto" (OC, I, p. 668).

${ }^{33}$ OC, l, p. 691-692.

${ }^{34}$ Virgília é caracterizada como o ser e o não-ser. Nela convivem, testemunhados por Brás Cubas, os aspectos da esposa séria, da mãe carinhosa e da amante (RIBEIRO, 2006, p. 254). "Não é o marido ciumento que fantasia a dissimulação de uma esposa que pode ser culpada ou não e que transforma a sua narrativa em libelo acusatório" (RIBEIRO, 2006, p. 256). Brás Cubas tem quatro envolvimentos ao longo da narrativa: Marcela, Eugênia, Virgília e Nhá Loló. Curioso é que das quatro, as duas relações consumadas, são marcadas pela dualidade: Marcela mantém relação concomitante com dois amantes, Brás e Xavier, sem que um deles esteja avisado (RIBEIRO, 2006, p. 256-258). 
com Eliane Robert Moraes, "uma das principais características das heroínas de Machado é a dissimulação", característica essa que, enquanto emula resignação com o poder senhorial da sociedade, na verdade pode esconder atuando como disfarce, para benefício próprio, seus verdadeiros sentimentos (2009, p. 285-286). Essa forma de não submissão insondável pode servir como exemplo da perspectiva estratégica.

Por fim, antes de cedermos o lugar a Capitu, apontaremos brevemente uma aproximação entre Virgília e Pandora. Muito embora essa aproximação não seja retirada da abordagem de Maia Neto, julgamos que ela é coerente com a leitura da personagem segundo a perspectiva da filosofia cética.

É curiosa a aproximação que Schwarz faz entre Virgília e a personificação feminina da Natureza, designando-a em termos barrocos. Sua beleza, pelo referencial da boca, é descrita como fresca como a madrugada e insaciável como a morte (SCHWARZ, 2012, p. 142-143).

Assim, na expressão que está nos interessando, a madrugada não pertence ao começo, nem a morte pertence ao final: as duas estão juntas em pleno meio-dia de Virgília. Note-se que madrugada aqui não tem nada de virginal: um frescor que, por assim dizer, se acentua com o uso. Por sua vez, a morte é ávida, e não decrépita. A surpresa da formulação está na interpenetração de extremos que pareceriam opostos. Tanto que os adjetivos de um podem servir ao outro, ou se podem somar. Fresca e insaciável, excedendo - no plano sexual - tudo o que um homem pode oferecer, a madrugada é mortal. Ao passo que a morte está sempre madrugando (SCHWARZ, 2012, p. 143).

Capitu. Inicialmente, podemos caracterizar Capitu cotejando-a com Virgília. A distinção entre essas duas personagens marca a evolução do ceticismo presente na ficção machadiana. Virgília representa a dualidade. Isso porque suas mentiras e dissimulações são testemunhadas pelo seu amante, Brás personagem, sendo relatadas pelo defunto-autor. Capitu, por sua vez representa opacidade, já que ela permanece insondável ao narrador, que é incapaz de realizar qualquer afirmação sobre a realidade para além das suas aparências (MAIA NETO, 2016, p. 287). “O foco narrativo restrito não tem acesso às intenções e ações reais subjetivas de Capitu" (MAIA NETO, 2016, p. 287).

Capitu representa a perspectiva estratégica ${ }^{35}$ como a opacidade dos estados subjetivos para o observador, o que leva o narrador, Dom Casmurro, mais perto da perspectiva cética do que, por exemplo, Brás Cubas. O que distingue Capitu de Virgília - ambas personificações da perspectiva estratégica - é que, se da segunda pode-se dizer que objetivamente incorre no adultério pelo acesso que o narrador tem das suas motivações subjetivas, a primeira, essencialmente misteriosa, permanece imponderável ${ }^{36}$ (MAIA NETO, 2007A, p. 141-144).

Com efeito, não há continuidade entre o discurso de Capitu e sua condição subjetiva. Não se pode afirmar que esta última seja inconsistente com o que é expresso nos gestos e palavras, nem permite a conclusão de que Capitu é movida por mero interesse. (MAIA NETO, 2007A, p. 144-145).

Antes, porém, de nos determos no elemento da opacidade cuja função Capitu exerce por excelência, é importante ponderar brevemente a respeito do nome dessa personagem magistral e sua relação com a obra de Machado.

Como nome não usual que remete ao Capitólio, a mais alta colina da cidade de Roma que abrigava o arquivo da República e sediava tanto o poder republicano quanto o imperial, Capitolina

\footnotetext{
35 “Era, em suma, uma mulher superior, seja pela inteligência, seja pela sede de saber, pela capacidade de adaptar-se, pela percepção do jogo social. Nisto fica muito distante das heroínas românticas e das mulheres idealizadas tão comuns no romance dos novecentos" (RIBEIRO, 2006, p. 309).

36 (MAIA NETO, 2007A, p. 143).
} 
pode ter nele uma representação da sua dubiedade. $O$ adjetivo capitolino tem valor simbólico na história romana, o que fez com que indivíduos considerados insignes o recebessem como uma alcunha cuja significação remetia ao glorioso. Machado também emprega o adjetivo em conformidade com essa acepção em alguns momentos de sua obra. O nome também pode ser representativo por ser indicativo de sede de poder tanto republicano quanto imperial como uma marca da ambigüidade que caracteriza a personagem, designando, quiçá também com alguma ironia, as virtudes de Capitu. Na história romana, o adjetivo era acrescido aos nomes de algumas personagens. Dentre estes, o cônsul Marco Mânlio seria o único, como Capitu, marcado pela ambigüidade, pois o Capitólio foi palco tanto das suas glórias quanto de sua morte (MAIA NETO, 2013, p. 60).

Sob a perspectiva do paralelo com Mânlio, Capitu pode também ser vista como constituindo dois momentos das memórias de Bento sobre a vida com ela: um sendo anterior ao casamento - a fase heróica de conquistas, o idílio, que corresponde à glória de Mânlio salvando os romanos da escravidão pelos gauleses, o que constitui paralelo com Capitu salvar Bento da escravidão da promessa da mãe para a lgreja - e o outro posterior, alternando grande felicidade e suspeita, com este elemento terminando por engolfar o primeiro; na visão de Dom Casmurro, esse momento pode ser cotejado com as ações viciosas e a desgraça de Mânlio (MAIA NETO, 2013, p. 62-63).

Segundo Maia Neto, entre os autores presentes na biblioteca de Machado, é Tito Lívio, em comparação aos demais ${ }^{37}$, o mais significativamente machadiano ao tratar da figura de Marco Mânlio. Isso por ser o único que lança dúvidas sobre a culpa do Capitolino, o que o torna padecedor, do ponto de vista jurídico, da mesma situação de Capitu (2013, p. 69).

Tito Lívio dá a entender que a única evidência da culpabilidade no que diz respeito à acusação mais grave é a força e unanimidade da convicção dos acusadores. Ora, o ceticismo de Montaigne - autor chave no romance de Machado - expõe amplamente a fragilidade de tal "evidência". Estas considerações reequilibram a balança que parecia pender para a hipótese da infidelidade, mostrando que a comparação com as fontes disponíveis do caso capitolino não são capazes - felizmente - de elucidar o enigma da nossa Capitu (MAIA NETO, 2013, p. 69).

A referência desse personagem, Marco Mânlio Capitolino, é coerente tanto com o momento da equipolência entre as posições céticas e dogmáticas como também com o traço fideísta que, confrontando-se com a irremediável necessidade de agir que o mundo impõe, faz com que o cético adote o salto de fé em relação à epoche. Trata-se da manutenção da epoche de maneira concomitante com a falta de fundamento dos juízos. Diante disso, o cético fideísta quando confrontado coma necessidade incontornável da ação, adota critérios pragmáticos para ela. Face, por exemplo, à necessidade de escolher entre aceitar ou não a fé religiosa, ele usa o critério pragmático observando as vantagens em declarar-se religioso (MAIA NETO, 2016, p. 288-289).

Acho que Bento faz um cálculo similar. A vida com Capitu - ou seja, a vida real - era cheia de prazer e alegria, mas também cheia de angústia. Esta angústia era tão terrível - tal é a força que crenças completamente sem fundamento têm sobre nós - que isolar-se do fluxo dos fenômenos (do mundo) era a opção pragmaticamente justificada (MAIA NETO, 2016, p. 289).

Capitu, por meio das variações cujos elementos centrais são a beleza e o fascínio, significa um problema de inteligibilidade. A personagem encarna o aspecto dúbio cuja opacidade problematiza a verdade (MAIA NETO, 2007A, p. 58). Capitu - e esse é também o papel de Sancha -, por metonímia, expõe a faceta da vida social enquanto meio que não é nem transparente nem unívoco por conta da polissemia que cada um dos seus gestos pode significar. ${ }^{38}$ Desse

\footnotetext{
${ }^{37}$ Além de Tito Lívio, podemos elencar também Plutarco e Montaigne. Conferir (MAIA NETO, 2013, p. 60-61).

${ }^{38}$ Exemplos são os episódios da despedia de Sancha em que Bento enxerga intento de adultério (OC, I, p. 1022-1023) e de Capitu
} 
modo, ambas representam o aspecto da vida exterior em que as incertezas são decorrentes do caráter contraditório e indiscernível das aparências (MAIA NETO, 2007A, p. 156-157). Entretanto, Capitu é hermética ao entendimento de uma forma cabal. Se após o casamento Capitu pode ser compreendida como a vida tornada opaca, angustiosa e ambígua à percepção do observador cético (MAIA NETO, 2007A, p. 155), o narrador Casmurro passa a considerar esse atributo capitolino de forma retroativa, o que aparece na célebre questão sobre se a mulher já estava na menina (OC, I, p. 1043).

A personagem, portanto, evidencia o aspecto da realidade exterior opaco à fundamentação epistemológica das opiniões. Trata-se das dúvidas inerentes ao entendimento do mundo, em meio às quais Dom Casmurro permanece à deriva. Trata-se das impressões contraditórias da vida exterior (MAIA NETO, 2007A, p. 138- 139). Capitu está situada no horizonte cético sendo representante da variabilidade e contraditoriedade que perturbam o observador, para quem permanece insondável. Além disso, a personagem representa o movimento e a atração que este é capaz de exercer ${ }^{39}$. Esses aspectos de Capitu, verbos e características ligados ao mar $^{40}$, ecoam aspectos tradicionais do ceticismo.

Ao descrevê-la, Dom Casmurro usa a metáfora do mar e seu movimento; ora, esta é uma tradicional metáfora cética cuja origem remonta à doutrina heracliteana dos mares, como exposto no Thaetetus de Platão e que é bastante explorado pelos primeiros céticos modernos, especialmente por François de La Mothe Le Veyer. Tudo muda continuamente, logo, nenhum conhecimento - que necessita de alguma estabilidade de vida - é possível. Dom Casmurro intensifica esta imagem já que o mundo - representado por Capitu - parece para Bento não apenas como um mar em movimento, mas como um mar de ressaca (MAIA NETO, 2016, p. 287).

Como Capitu representa o fluxo incessante e cambiante dos fenômenos, ela representa com isso nada menos que o próprio mundo (MAIA NETO, 2016, p. 287 - 289). Essa é segundo Maia Neto a personagem machadiana que melhor representa a realidade das coisas conforme o pirronismo (2007B, p. 219).

O fragmento mais importante que relata a filosofia de Pirro é um testemunhado por Timão e preservado por Eusébio que citou uma obra desaparecida de Aristocles. Conhecido como fragmento sobre a indiferença das coisas, afirma que quem quer ser feliz precisa responder três perguntas: o que são as coisas por natureza, que atitude o sábio deve ter em face delas e o que resultará desta atitude. Segundo Timão Pirro teria dito que as coisas são por natureza igualmente indiferentes, instáveis e inarbitráveis, que a atitude do sábio deve ser então a de não confiança nas percepções e opiniões, e que o resultado desta atitude será, primeiro, o silêncio (aphasia) e, em seguida, a tranqüilidade (ataraxia) (MAIA NETO, 2007B, p. 219).

arrumando os cabelos diante do espelho após o enterro de Escobar sendo surpreendida aos prantos por Santiago (OC, I, p. 1028-1029). Essa passagem do enterro de Escobar também pode servir para explicitar o aspecto impenetrável das aparências constituindo a vida social como um todo, quando Santiago, enciumado pela tristeza de Capitu ao contemplar o falecido, tem dificuldades para ler o discurso que preparara (OC, l, p. 1025-1026). "As aparências enganam, e os presentes aplaudem a comoção do amigo, num exemplo de ilusão possível. Parecia amizade, mas não era, como as lágrimas de Capitu - aliás poucas - podiam parecer adúlteras sem o serem, como a semelhança entre Ezequiel e Escobar podia ser acaso" (SCHWARZ, 2006, p. 15-16). Muito embora saibamos, pelo acesso à perspectiva de Santiago, qual a real natureza da sua aparência no momento em que interrompe o discurso durante o enterro de Escobar, o que está em jogo é que a perspectiva restrita torna as aparências opacas. A perspectiva da audiência do discurso é restrita. Daí vem a necessidade desse foco narrativo para o tratamento da filosofia cética.

39 (MAIA NETO, 2016, p. 287).

40 Caldwell também considera - em uma perspectiva diferente - a relação entre Capitu e o mar. A esse respeito, conferir (CALDWELL, 2008, p. 143-145). 
Capitu é inarbitrável ${ }^{41}$. Ela leva a caracterização das coisas feita por Pirro e relatada por Timão para a subjetividade, o que coloca o ceticismo proposto na ficção machadiana como mais próximo daquele presente na modernidade. Muito embora Machado tenha como fontes principais Montaigne e Pascal, é importante lembrar que ele dispunha de um exemplar de Descartes na sua biblioteca particular, além de fazer referência à dúvida e ao cogito cartesianos no conto Ex Cathedra (MAIA NETO, 2007B, p. 226). A subjetividade de Capitu representa a realidade opaca, incerta e obscura para o observador cético (MAIA NETO, 2007B, p. 219-220), bem como, por extensão, o próprio mistério do mundo.

Como Capitu aparece como inescrutável, a posição de Dom Casmurro em relação à sua infidelidade não é fundamentada em razões filosóficas ou fatores epistêmicos, mas por paixões e crenças prévias igualmente gratuitas e precárias. Após formular esse juízo, Santiago o segue até que Dom Casmurro o rememora, pois, diante da impossibilidade prática de viver sem crenças, ele mantém aquela que determinou um curso de vida que já não pode mais ser modificado, em uma atitude semelhante ao fideísmo (MAIA NETO, 2007B, p. 219-220). Isso porque, de acordo com o fragmento de Pirro, a aphasia seria a atitude adequada diante de Capitu.

Voltando ao fragmento de Pirro, como nem as sensações nem as opiniões são verdadeiras ou falsas, nada podemos dizer (aphasia) ou, se formos dizer alguma coisa (como diz Dom Casmurro em suas memórias), devemos dizer que 'não mais' a) que Capitu traiu, b) que Capitu não traiu, c) que Capitu traiu e não traiu d) que Capitu nem traiu nem não traiu. (a), (b), (c) e (d) são eqüipolentes.

O quadrilema é a única afirmação capaz de expressar instabilidade e inescrutabilidade com que Capitu aparece para o observador pirrônico. Em que pese a equipolência que ele próprio constrói em sua narrativa, Dom Cassmurro afirma (a) no final do seu livro. Trata-se de uma afirmação de tipo 'fideísta' quanto a sua forma (evidentemente não quanto ao seu conteúdo) (MAIA NETO, 2007B, p. 220).

Fidélia. A última das mulheres estratégicas machadianas pertence ao registro das personagens cujo nome contém uma ironia, a exemplo do Félix, de Ressureição, cuja felicidade é obstruída pelas dúvidas que cultiva, Fidélia não guarda fidelidade estrita ao marido morto, pois contrai segundas núpcias com Tristão ${ }^{42}$, nem com a família Aguiar, os "pais postiços" que abandona para morar em Portugal (MAIA NETO, 2013, p. 59). Entretanto, veremos que essa ação da personagem não é mais enquadrada no registro de dualidade da vida exterior, cuja representação analisamos em Virgília. Enquanto representativa da vida social, Fidélia, a essa altura da ficção cética machadiana mostra uma perspectiva diferente da vida exterior, distinta também daquela exemplificada por Capitu, da opacidade que causa perturbação. Fidélia é o foco da cognição estética do memorialista, cuja atenção, em lugar de observar as motivações, restringe-se às aparências (MAIA NETO, 2007A, p. 169). A partir dessa postura, a crise cética encontra sua solução: no memorial que recebe as observações estético-cognitivas do seu autor (MAIA NETO, 2007A, p. 59).

Importa observar que a contemplação estética de Aires é desinteressada. Ele observa Fidélia com um objetivo diverso daquele nutrido por Tristão.

\footnotetext{
${ }^{41}$ Ainda que Caldwell defenda um acesso aos estados subjetivos de Capitu, é importante observar que, assim mesmo, sobrevivem os exemplos em que sua conduta é opaca. Quando Capitu é confrontada com a acusação de Santiago sobre a semelhança de Ezequiel e Escobar e responde que a similaridade é 'vontade de Deus', tal resposta permanece insondável, podendo apenas ser alvo de especulação. "Talvez ela queira, com isso, dizer que ela, assim como Santiago, está sendo punida por sua parte na quebra do juramento de Dona Glória" (CALDWELL, 2008, p. 110). O levantamento da defesa de Capitu não deixa, ele próprio, de inserir-se no registro das eqüipolências. Conferir a esse respeito (CALDWELL, 2008, p. 101-125).

${ }^{42}$ Sobre interpretações onomásticas da personagem, ver (PAES in OC, I, p. 168-170).
} 
No triângulo amoroso do romance, ele substitui com uma atitude estético-cognitiva a atitude de amor/paixão de seus antecessores. Ele não é um ex-amante como Brás Cubas, nem um ex-marido, como Dom Casmurro, mas alguém que durante a primeira parte do romance sublima seu interesse inicial em tentar conquistar Fidélia (MAIA NETO, 2016, p. 290).

A atitude de Aires é cognitiva, pois busca resolver a questão sobre se ela permanecerá viúva ou casará com Tristão e é estética, pois sua contemplação é desinteressada. Ou seja, Aires observa as aparências de Fidélia e levanta hipóteses, sem o interesse passional que é demonstrado por Tristão.

Maia Neto, no que pese não considerar que o modelo kantiano de contemplação desinteressada possa servir para se chegar a essa característica de Fidélia, tal modelo não é, afirma, incompatível com a tradição cética, pois, embora o cético suspenda o juízo sobre a essência, ele reconhece o que aparece, e a valorização da aparência enquanto elemento de fruição estética é tida como importante por um dos principais céticos do século XVII, François de La Mothe le Veyer, de tal modo que a contemplação exercida por Aires é desinteressada e desengajada, como a fruição de uma obra de arte (MAIA NETO, 2016, p. 290-291). "A forma literária que escoIhe é a mais adequada à sua posição: um diário em que ele deposita sua impressão estética e faz suas observações cognitivas sobre o comportamento de Fidélia" (MAIA NETO, 2016, p. 291). Essa prática de compor um memorial também é uma pedra de toque com o ceticismo, tendo em vista a regra pirrônica de se adotar uma determinada arte (MAIA NETO, 2007B, p. 222).

Nesse contexto de observação não dogmática e interesse não passional, Fidélia representa a conciliação de contrários, de modo que nela, atitudes e disposições diversas tornam-se compreensíveis à luz de circunstâncias igualmente distintas (MAIA NETO, 2007A, p. 177). A personagem, portanto, unifica e compatibiliza duas fidelidades distintas:

pode-se falar, sem dualidade, de duas Fidélias diversas. A viúva, definida em relação a Noronha, e a casada, definida em relação a Tristão, se harmonizam. Não há a afirmação de uma subjetividade essencial, independente de cada relação, definida num quadro 'a priori' que determina conduta e sentimentos exclusivos para cada estado civil. (MAIA NETO, 2007A, p. 178).

Para concluir. As aparências em Fidélia são distintas daquelas vistas em Virgília e Capítu. Em Virgília, as aparências são dúbias, tanto de verdade como de mentira. Já em Capitu, são opacas e, por isso, misteriosas. Fidélia, por sua vez, as apresenta como intercambiáveis: a viúva triste e a feliz noiva de Tristão (MAIA NETO, 2016, p. 292). "A lealdade de Fidélia para com seu falecido marido e seu casamento com Tristão são contraditórias apenas dentro de um sistema dogmático de crenças que assume uma única verdade essencial" (MAIA NETO, 2016, p. 292).

\section{Considerações finais}

As personagens femininas são fundamentais como uma chave de leitura para a compreensão do ceticismo na ficção machadiana. Elas refletem os aspectos preponderantes da vida social além de anteciparem a adaptação em relação a esta que o narrador cético apenas terá rematado na figura do Conselheiro Aires.

Na segunda fase machadiana as mulheres estratégicas eclipsam as mulheres de espírito, o que é coerente com o foco narrativo restritivo e o estabelecimento da perspectiva cética. Espelhando em si os atributos característicos da vida exterior em cada um dos momentos principais: dualidade, opacidade e oposições intercambiáveis.

Será apenas com a forma final do observador cético, o Conselheiro Aires, que o homem de espírito encontra o seu lugar (MAIA NETO, 2016, p. 290). Em comparação com o tolo - que se torna 
uma versão mais refinada enquanto homem estratégico - e das mulheres de espírito - que cedem espaço às mulheres estratégicas, à vontade na vida exterior - o homem de espírito demora a encontrar seu ponto de ajuste em relação à crise cética causada pela hegemonia da vida exterior que inviabiliza a postura dogmático-ingênua, desalojando a verdade do foco narrativo restrito.

As personagens femininas encarnam o desenvolvimento da perspectiva filosófica cética na ficção machadiana. As mulheres de espírito, tornando-se estratégicas, adaptam-se melhor à perda da hegemonia da verdade que representa a impossibilidade da visão dogmática de mundo, quando a esfera da paz doméstica não é apenas assimilada à vida exterior, mas torna-se mesmo o centro da vida social ${ }^{43}$. Os homens de espírito, primeiro, tornam-se personagens problemáticos, antes de atravessarem a crisálida do narrador cético cuja versão mais bem-acabada é o Conselheiro Aires. Desde os contos e romances de 1872 à 1878, contudo, as personagens femininas já rompem de forma bem sucedida com a atitude ingênua, as mulheres de espírito convertendo-se em complexas mulheres estratégicas, cada uma das principais entre elas representando um elemento da composição que completa o ceticismo machadiano: Virgília, o aspecto moderno pascaliano, Capitu, a opacidade cuja resultante é a equipolência e Fidélia, o traço estético-cognitivo. As três personagens enfeixam a solução original machadiana para o dilema da possibilidade de se viver o ceticismo.

\section{Referências}

ASSIS, M. Obra completa em quatro volumes. São Paulo: Editora Nova Aguilar, 2015.

CALDWELL, H. O Otelo brasileiro de Machado de Assis: um estudo de Dom Casmurro. Tradução de Fábio Fonseca de Melo. Cotia: Ateliê Editorial, 2008.

COMMELIN, P. Mitologia grega e romana. Tradução de Eduardo Brandão. 2. ed. São Paulo: Martins Fontes, 1997.

DIÔGENES L. Vidas e doutrinas dos filósofos ilustres. Tradução de Mário da Gama. Brasília: Editora Universidade de Brasília, 2008.

GUIRAND, F. História das mitologias I. Tradução de Leonor Santana Bárbara. Lisboa: Edições 70, 2006.

KRAUSE, G. B. Quem me dera: o ceticismo de Machado de Assis. Sképsis, n. 1. 2007. p. 171-183.

MAIA NETO, J. R. O desenvolvimento de uma visão de vida cética na ficção de Machado de Assis. In: ROCHA, J. C. C. Machado de Assis: lido e relido. São Paulo: Alameda, Campinas: Editora UNICAMP, 2016.

MAIA NETO, J. R. O delito capitolino. Aletria, n. 1, v. 23, jan/abr 2013. p. 59-71.

\footnotetext{
43 Um paralelo entre o desajuste maior que os personagens masculinos apresentam em relação às femininas na vida exterior pode ser traçado quando se observa o desempenho da função social da mulher no contexto da quebra da velha estrutura doméstica nas cidades; na colônia, acontecia uma nova sociabilidade marcada pelo processo de exteriorização da família (MURICY, 1988, p 57). "Os homens, acostumados ao regime paternalista, tornaram-se mais mal-ajustados que as mulheres. Eles esconderam, na rotina burocrática ou na mais completa decadência, sua profunda incapacidade para enfrentar com sucesso os novos requisitos de comportamento, enquanto as mulheres se acomodavam com surpreendente rapidez às exigências da vida moderna. A Corte pedia a 'mulher de salão', a 'mulher da rua'. Os grandes negócios do marido a requeriam, o pequeno comércio da rua a chamava. A mulher de posses devia expor-se ao mundo: nos salões das residências, nos teatros, nas recepções oficias, nos restaurantes que começavam a surgir. Abandonavam a alcova, a intimidade auto-suficiente das casas, tiravam as mantilhas ibéricas e ganhavam as ruas em busca de artigos de luxo franceses e ingleses" (MURICY, 1988, p. 57).
} 
MAIA NETO, J. R. O ceticismo na obra de Machado de Assis. São Paulo: Annablume, 2007A.MAIA NETO, J. R. Machado, um cético brasileiro: reposta a Paulo Margutti e a Gustavo Bernardo. Sképsis, n. 1, 2007B. p. 212-226.

MAIA NETO, J. R. Machado de Assis: ceticismo e literatura. In: KRAUSE, G. B. Literatura e ceticismo. São Paulo: Annablume, 2005. p. 11-24.

MARCH, J. Mitos clássicos. Tradução de Maria Alice Máximo. São Paulo: Civilização Brasileira, 2015. MARGUTTI, P. História da filosofia do Brasil (1500 - hoje): 1a parte: o período colonial (1500 1822). São Paulo: Edições Loyola, 2013.

MARGUTTI, P. Machado, o brasileiro pirrônico? Um debate com Maia Neto. Sképsis, n. 1, 2007. p. 183-212.

MORAES, E. R. O decoro de uma cortesã. Estudos Avançados, n. 35, 2019. p. 317-329.

MORAES, E. R. “Um vasto prazer, quieto e profundo". Estudos Avançados, n. 23, 2009. p. 271-288.

MARTINS, A. L. Machado de Assis: o filósofo brasileiro. Porto Alegre: Editora Fi, 2017.

MURICY, K. A razão cética: Machado de Assis e as questões de seu tempo. São Paulo: Companhia das Letras, 1988.

PAES, J. P. Um aprendiz de morto. In: Machado de Assis obra completa em quatro volumes. São Paulo: Editora Nova Aguilar, 2015. p. 163-179.

PASCAL, B. Pensamentos. Tradução de Mário Laranjeira. São Paulo: Martins Fontes, 2005.

PHILIPOV, R. Edgar Allan Poe e Machado de Assis: intertextualidade e identidade. Itinerários. Araraquara, n. 33, jul/dez 2011. p. 39-47.

POPKIN, R. História do ceticismo de Erasmo a Spinoza. Tradução de Danilo Marcondes. Rio de Janeiro: Francisco Alves, 2000.

REALE, M. A filosofia na obra de Machado de Assis e Antologia filosófica de Machado de Assis. São Paulo: Livraria Pioneira Editora, 1973.

RIBEIRO, L. F. Mulheres de papel: um estudo do imaginário em José de Alencar e Machado de Assis. Niterói: EDUFF, 2006.

SCHWARZ, R. Um mestre na periferia do capitalismo: Machado de Assis. 2. ed. São Paulo: Duas Cidades; Editora 34, 2012.

SCHWARZ, R. A poesia envenenada de Dom Casmurro. In: Duas meninas. 2. ed. São Paulo: Companhia das Letras, 2006.

WEIL, E. Lógica da filosofia. São Paulo: É realizações, 2012.

\section{Sobre o autor}

\section{Daniel Benevides Soares}

Doutor em Filosofia pela Universidade Federal do Ceará (UFC). Professor da Faculdade Católica de Fortaleza (FCF). 